\title{
HOW TO TELL
}

\section{The Age of the Domestic Animals.}

$B X$

A. LIAUTARD. M.D., V.S.

\section{S F \\ 869 \\ . .69}




\section{LIBRARY OF CONGRESS,}

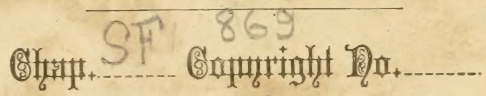

$$
\text { Shelf.L } 69
$$

UNITED STATES OF AMERICA. 




\section{HOW TO TELL}

\section{The Age of the Domestic Animals.}

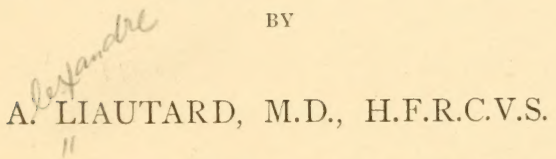

Professor of Anatomy, Operative Surgery and Sanitary Medicine to the American Veterinary College, N. Y.

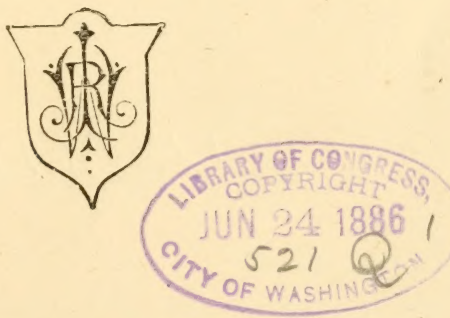

NEW YORK :

WILLIAM R. JENKINS, Veterinary Publisher and Bookseller, No. 850 Sixth Avenue, 1885. 
Copyright, 1885,

WILITAM R. JENKJNS.

$$
12-36184
$$

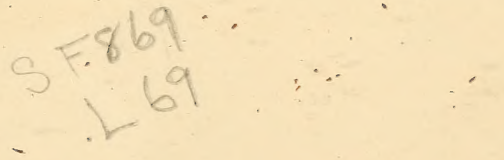




\section{HOWTOTELL THE AGE}

or $7 \mathrm{~m}$

\section{DOMESTIC ANIMALS.}

\section{THE AGE OF THE HORSE.}

The best and only scientific way to tell the age of animals is by the teeth. This knowledge, though put in practice for many years, was however never brought to almost perfection until Pessina and Girard, Jr., had made known all the characters, almost 
positive, by which the age of horses could be detected after eight years.

The lower incisives, in herbivora, are those which present us those characters; the upper being more irregular in their wear, and more difficult to examine and observe.

The lower incisives are divided into:-Nippers, A, (Fig. 1) ; Dividers, B ; Corners, C.

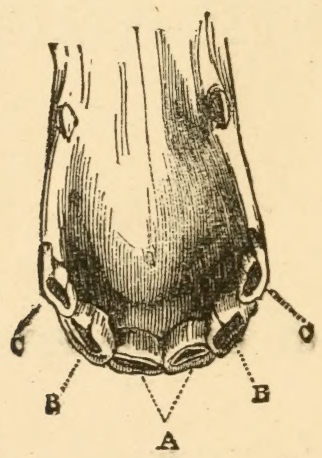

Fig. 1.

Each one has a free part, or crown, and a portion contained in the alveolar cavity, the root. 
The crown has an anterior A, (Fig. 2), and a pos-
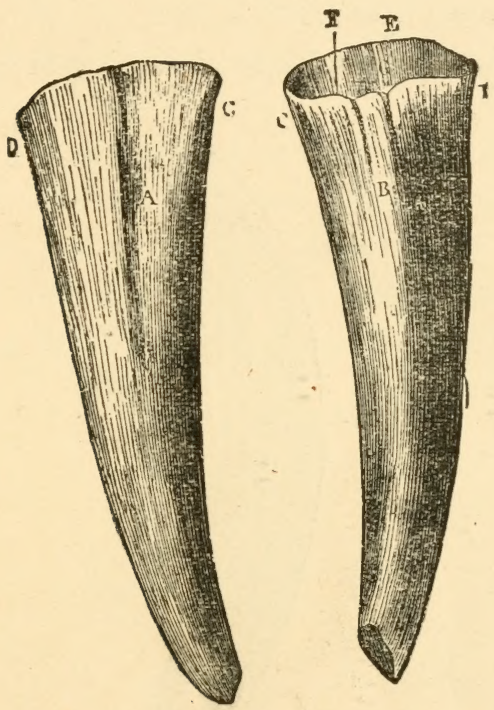

Fig. 2.

terior face $\mathrm{B}$, an internal $\mathrm{C}$, an external $\mathrm{D}$, an anterior $\mathrm{E}$, and a posterior border $\mathrm{F}$, surrounding at the superior extremity a cavity - the external dental cavity 
6

-which by the wearing of the borders becomes smaller, until, when almost disappeared, the tooth is said to be worn.

Fig. 3 shows a longitudinal section of a tooth, ex-

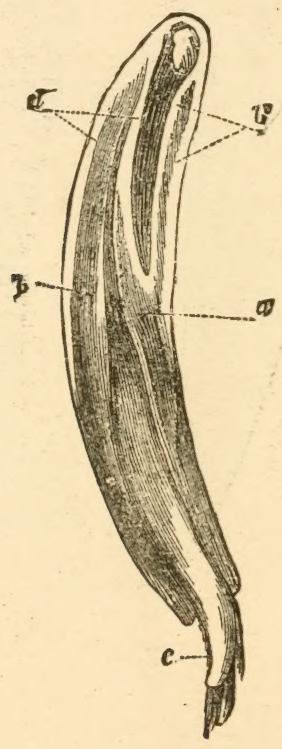

Fig. 3.

hibiting the structure: aa', enamel; bb', dentine or 
ivory, entirely surrounded by the enamel; c, dental pulp contained in the internal dental cavity, which shows itself on the dental table as a white mark. known as the dental star.

Fig. 4 is a transverse section, showing, a, the culde-sac of the external dental cavity surrounded by $\mathrm{b}$, central enamel, with c, the dental star-first shade of the internal dental cavity; the whole being surrounded by $d$, the surrounding enamel.

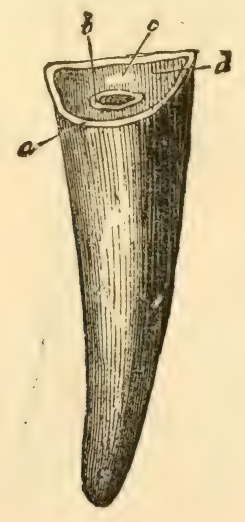

Fi ̧̧. 4. 
Fig. 5 points out the various shapes of the tooth in different parts of its length. First, flattened from forward backwards; then oval; then rounded, triangular and biangular, or flattened from side to side. These various shapes will be most essential in determining the age in the third period of life of the animal.

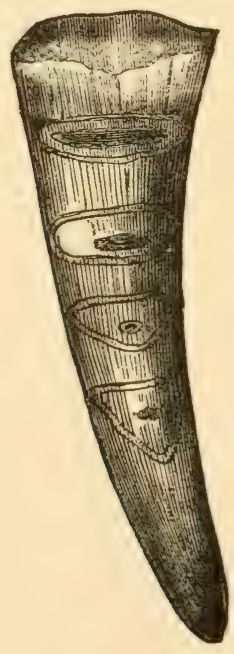

Fig. 5. 
Fig. 6 is a milk or cacluct tooth, and Fig. 7 represents the canine or tusks, which are missing in mares, or, if they exist, are only rudimentary.
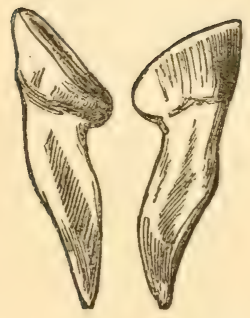

Fig. 6.
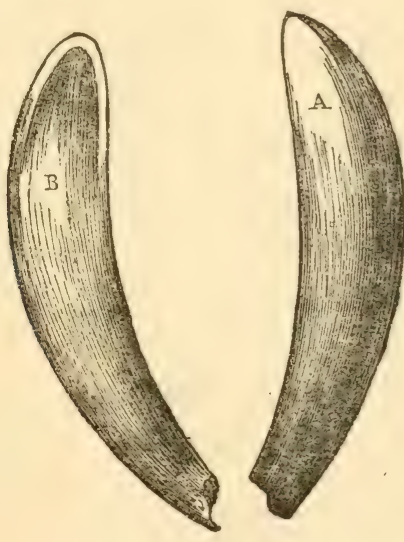

Fig. 7.

The incisors implanted in the two maxillary bones form what is known as the incisive arch. Meeting naturally those of the upper with those of the lower jaw they form two arches or curves-one from above below, and one from one side to the other, superoinferior and transversal arch, which vary much, ac- 
cording to the age of the animal and specially in the old ones.

A tooth is said to be worn when the external dental cavity has been much reduced in depth by wearing of the plate, and when there remains but the cul de sac of the same cavity surrounded by central enamel.

The life of an animal may be divided, taking in consideration the changes that take place in the evolution and alteration of the teeth, into three periods :

1st.-Change of caduct teeth.

2 d.-Growth and wearing of the adult.

3d.-Change in the adult.

FIRST PERIOD.

Colts are generally born in the Spring-no incisives present. First and second molar, and at the end of the first month, the third molar. The incisives, however, will make their appearance in from twenty-four hours to a few days. The nippers 
then come out by their anterior border, and at one month (Fig. 8) the posterior border is on a level.

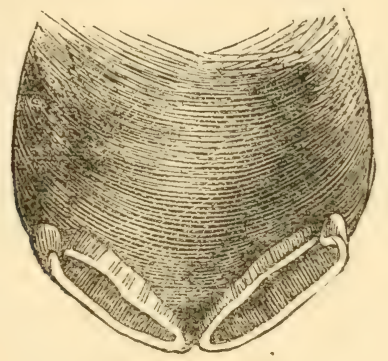

Fig. 8 .

About the same time the dividers begin to show themselves, and for some time the colt remains with eight incisives only, the growth taking place between thirty and forty days (Fig. 9).

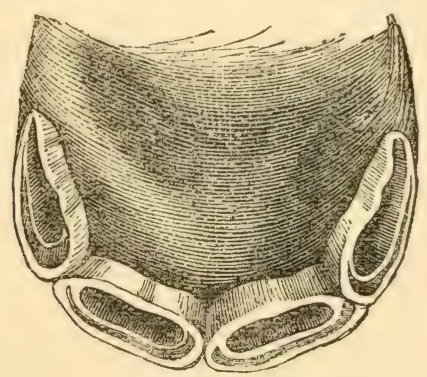

Fig. 9. 
The corners vary in their growth between the sixth and tenth months (Fig. 10).

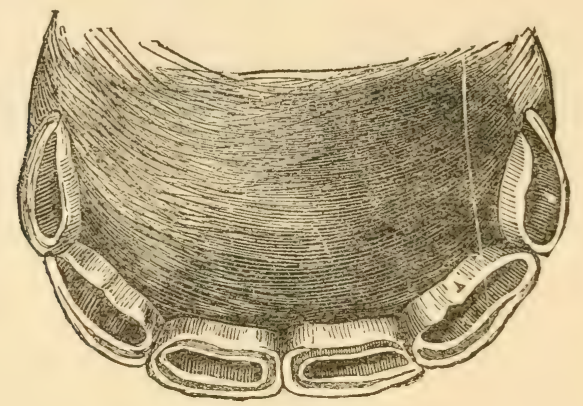

Fig, 10,

All these teeth, as they gradually appear, undergo a process of wearing, and in this way we obtain another character, viz.: that the caduct nippers are worn at abont ten months to a year, the dividers are at eighteen months, and at two years a full mouth of worn milk teeth is found.

SECOND PERIOD.

$2_{2}^{1}$ to $3_{2}^{1}$. Appearance and growth of the caduct nippers; milk dividers and corner teeth worn (Fig. 11). 


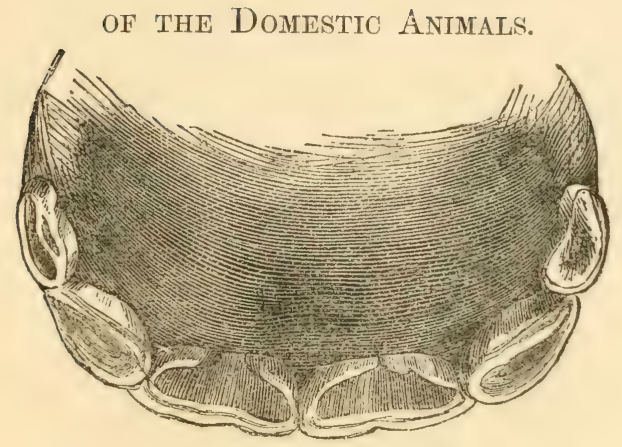

13

Fig. 11 .

$3_{2}^{1}$ to 4 . The nippers are those of second dentition. The permanent dividers make their appearance and grow out of the alveoli. Milk corner teeth worn loose, more or less, and ready to make room for the corners of second dentition (Fig. 12).

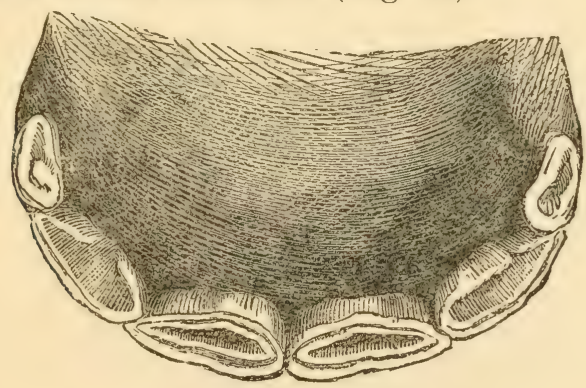

Fig. 12.

5 years. The nippers are worn more or less completely. The dividers are on a level with the nip- 
pers, and have their posterior border on a level with the anterior (Fig. 13).

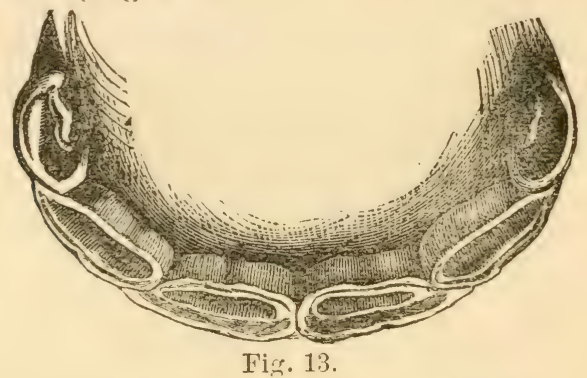

The corner's are lower than the dividers. There is a notch on the posterior border which is lower than the anterior. Sometimes this notch is very deep and extends down on the posterior face of the tooth, which is then called a shell tooth.

Then the corners are fresh and well grown out. The two dental arches form a regular semi-circle from above below, and from one side to the other.

6 years. The nippers are worn. The cul-de-sac of the external dental cavity is slightly worn in its middle.

The dividers are becoming worn ; the corners are on a level with the dividers, and present their anterior border worn down (Fig. 14). 


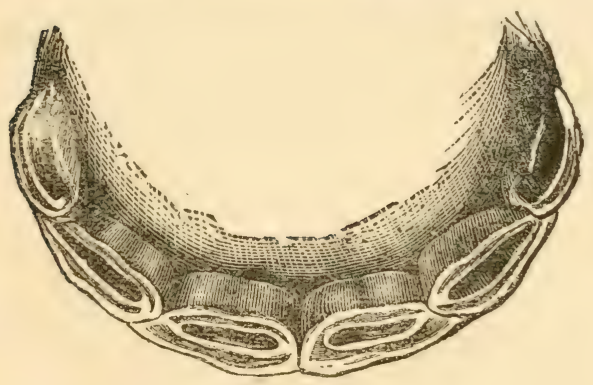

Fig. 14.

7 years. In the nippers the central enamel is becoming triangular. The diviiders are worn and have the external cul-de-sac slightly concave in the middle, while in the corners the posterior border is worn some and the tooth also begins to wear. It is not uncommon to find at that age a notch on the superior corners (Fig. 15).

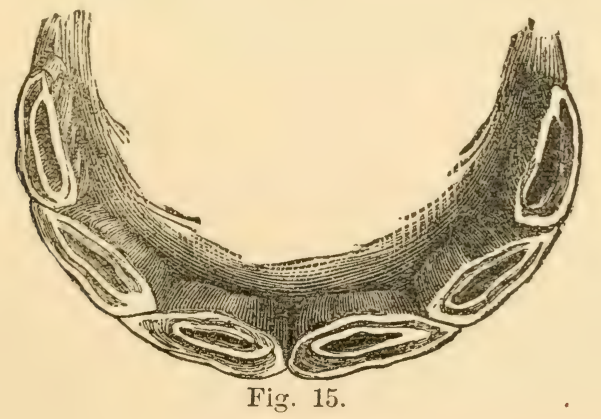


8 years. The nippers are oval, the central enamel is narrow and near the posterior border. The dividers are becoming oval and present a central enamel triangular. The corners are worn and show their central enamel concave well in the middle of the dental plate.

It is then, at that age of 8 years, that all the teeth of second dentition are worn (Fig. 16).

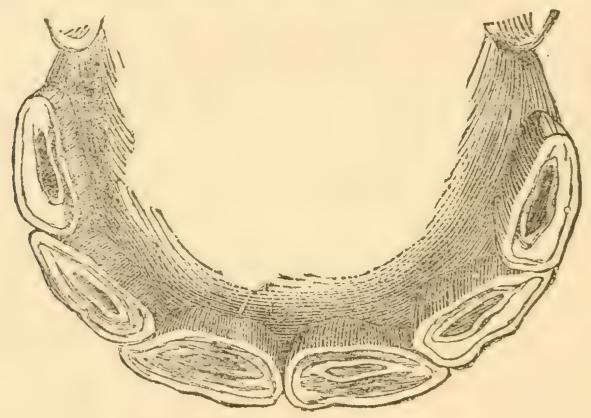

Fig. 16.

THIRD PERIOD.

9 years. The nippors are rounded, their central enanel round is very near the posterior border.

The dividers are yet oral and have the central enamel much like that of the nippers. 
In the conners, which are oval, the central enamel is still of a triangular shape (Fig. 17).

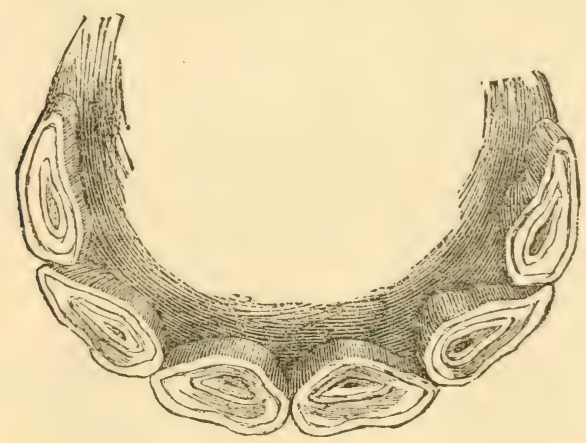

Fig. 17.

10 years. The nippers are rounded. The central enamel, which is round, is still nearer the posterior border, and is small. The dividers are nearly round, while the corners still remain oval. The superoinferior arch of the teeth becomes more angular.

11 years. 'The central enamel has disappeared in the nippers, while in the others it is very small. All the teeth are round. On the surface of the nippers - and between what remains of the central enamel on the dividers and corners, appears the cul-de-sac of 
the internal dental cavity, the dental star, as a small yellow or grayish band, transverse and situated between the enamel and the anterior borcler of the tooth.

12 years. All the teeth are rounded, and in all the central enamel has disappeared. The teeth meet still more in forming an angle open towards the mouth (Fig. 18).

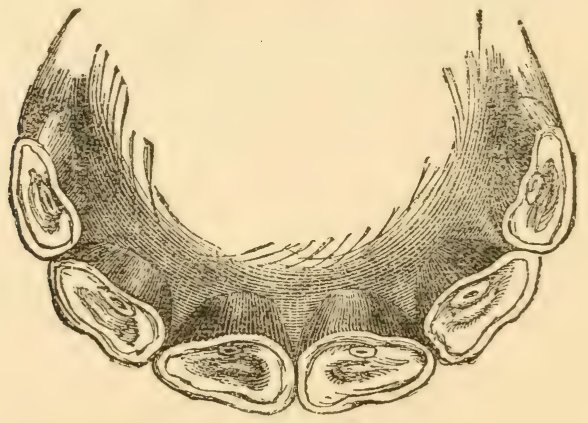

Fig. 18.

13 years. There is but little change with the above. All the teeth have yet the same shape-they are all rounded.

14 years. Thie nippers are becoming triangular. The dividers and corners remain rounded. The 
transverse arch of the teeth becomes narrower (Fig. 19).

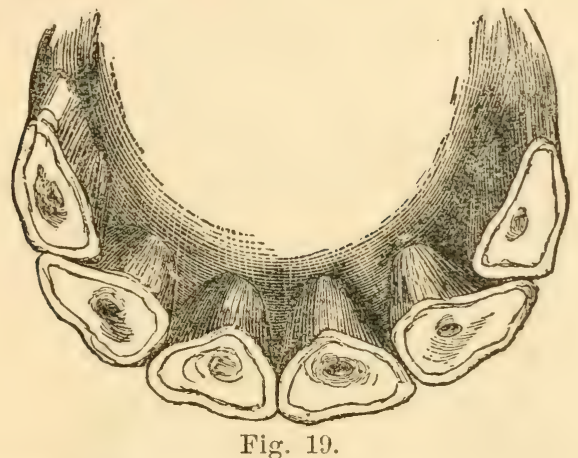

15 years. The nipper's are triangular, the dividers becoming so, the corners still rounded.

16 years. The dividers are nearly triangular and the corner teeth assuming that shape.

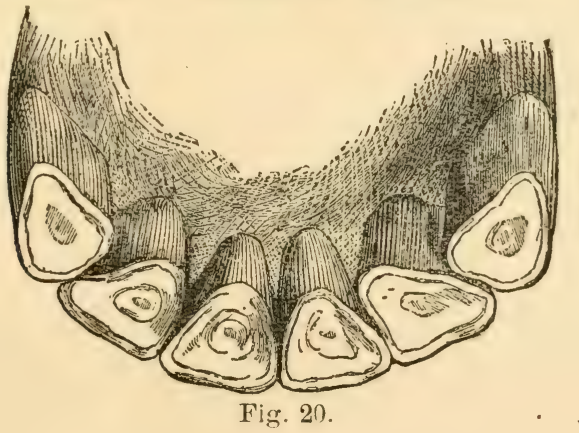


17 years. The corners are still more so (Fig. 20), and at 18 years the incisive arch is occupied with triangular teeth all through (Fig. 21).

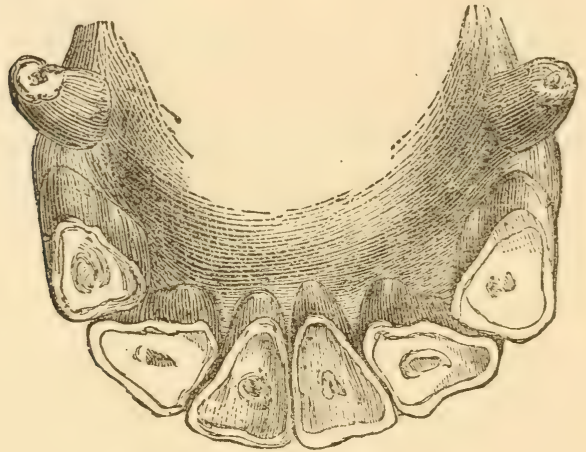

Fig. 21 .

19 years. The last change begins. The nippers assume a flattened sideways shape. At

20 years they are flattened from side to side, the dividers becoming so. At

21 years these last are also flattened sideways, when at

22 years the entire areh contains also teeth flattened in the same conditions, representing - the last 
form represented by the tooth towards its root (Fig. 22.)

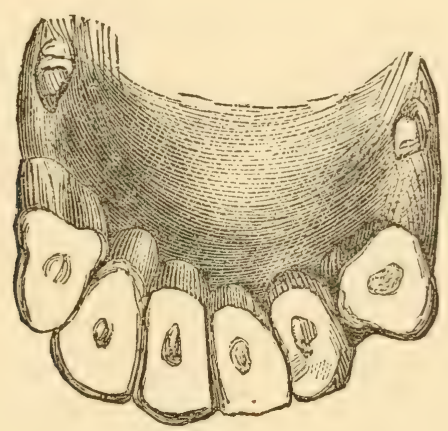

Fig. 22.

From 19 years the horizontality of the teeth is becoming more and more marked in such a manner that at 21 the inferior incisive arch is almost straight.

IRREGULAR MOUTHS.

On account of the peculiar nature of some of the elements of the tooth and of its anatomical structure, some jaws will either wear out too rapidly, while others will not, and on this account a young animal may present an old mouth, or an old individual will show all the characters of a young 
mouth. To approximate the age exhibited by such a mouth we will take off from the characters shown in the first case, or add to those of the second as many years as by approximation the tooth will show in measuring by lines the number which would be necessary to add or to take off to give the tosth its normal length.

Fig. 23 shows a defective jaw of an old horse, in

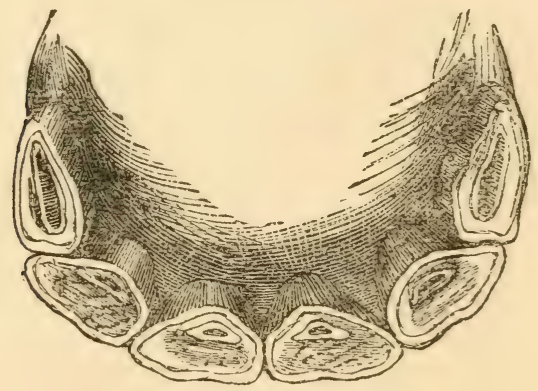

Fig. 23.

which the external dental cavity is yet remaining; the excessive length of the teeth allows us to make out the age by adding to the age given by the marks' of the crown as many years as there are lines in excess in its length. 


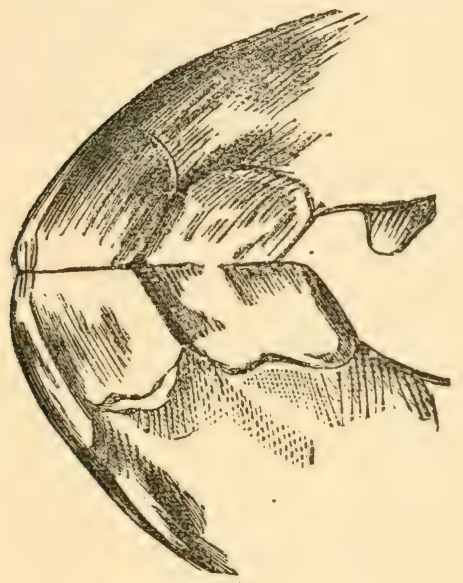

\section{- Fig. 24 .}

Fig. 24 shows the jaw of a cribber, with the wearing of the teeth on the front jaws.

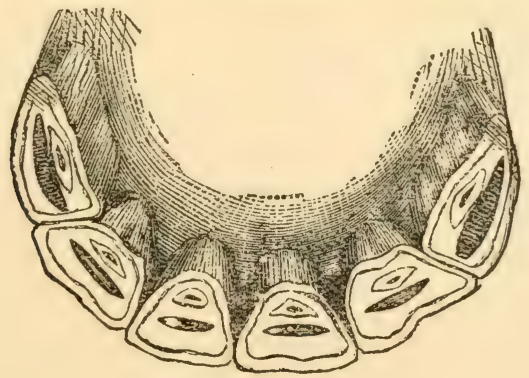

Fig. 25. 
24 Age of the Domestic Animals.

Fig. 25 is a bischopped mouth, easily recognized by the shape of the teeth and the presence of the dental star, which is not surrounded by the central enamel. 


\section{AGE OF CATTLE.}

The calf is often born with the nippers and first middle teeth, or at least they are out in the first eight days. Towards the twentieth day the second middle teeth appear, and at the end of a month the corners. However, the dental arch is not perfect and round or full until five or six months.

The wear of the teeth varying with the mode of feeding, in general it may be said that the milk nippers are worn at ten months, the first middle teeth at one year, the second middle incisives at fifteen months, and the corners at twenty months. At this time the

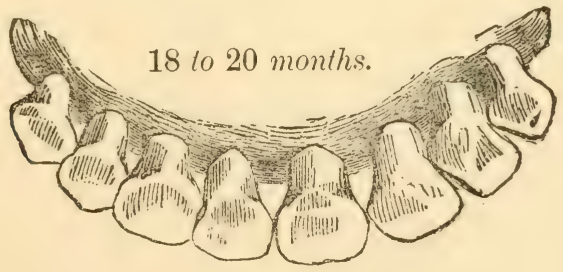

Fig. 26. 
caduct nippers are shed and replaced by the permanent nippers, which are at their full growth at two years.

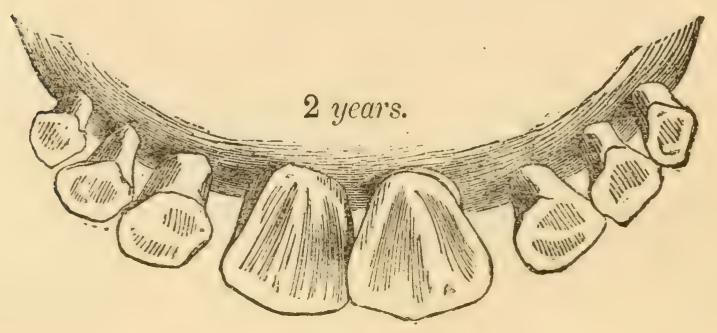

Fig. 27.

From two and a half to three years, appearance of the first middle permanent incisives (Fig. 28).

From three and a half to four, that of the second middle permanent incisives (Fig. 29).

From four and a half to five, that of the corners (Fig. 30).

From five to six years, the jaw is full well round.

From seven to eight, the nippers are worn.

From eight to nine, the middle teeth are worn. At ten years, the corners are worn. 


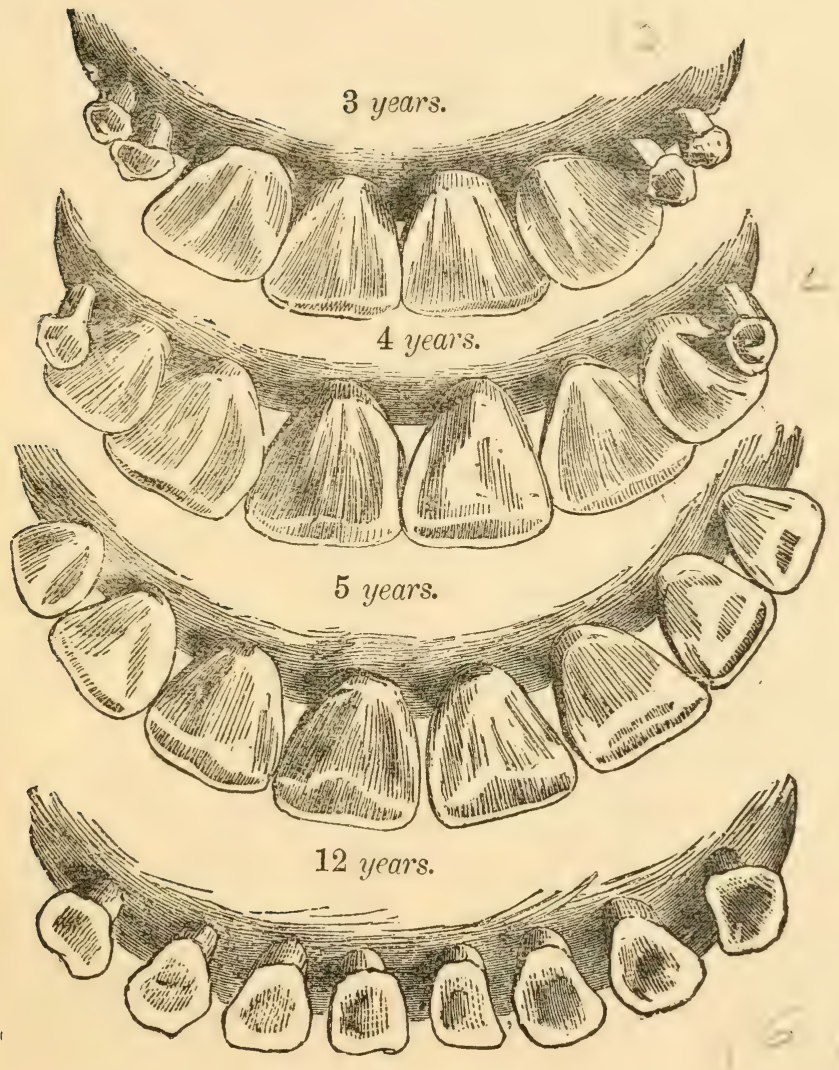

Fig. 28, 29, 30 and 31. 
At eleven years, the teeth begin to be quite short and somewhat separated.

At twelve, the separation of the teeth is well marked. The dental star appears as a white band, and the teeth assume a square rubbing shape (Fig. $31)$.

After this age the characters are only vague and approximative. 


\section{AGE OF SHEEP.}

The lamb is ordinarily bor'n without teeth, but in about twenty-five days these all grow, and the dental arch is full and round at three months (Fig. 32).

Towards eighteen months, the milk nippers are replaced by those of adults (Fig. 33).

3 months.

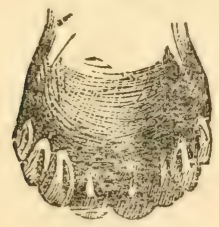

Fig. 32.

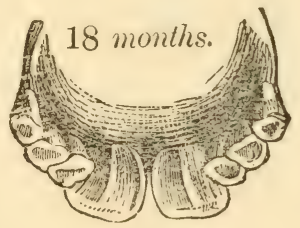

Fig. 33.

Towards two years, the first middle milk teeth drop and are replaced by the adult teeth (Fig. 34).

From three to three and a half years, the second middle adult teeth grow (Fig. 35).

From four to four and a half years, the corners of second dentition are appearing (Fig. 36). 
30 Age of the Donestic Animals.

At five years, the dental arch is round. At nine years, all the teeth are worn (Fig. 37).

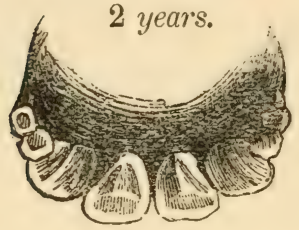

Fig. 34 .

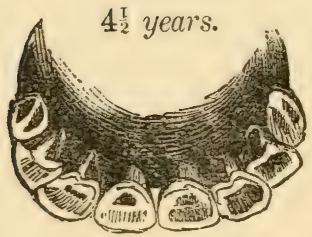

Fig. 36.

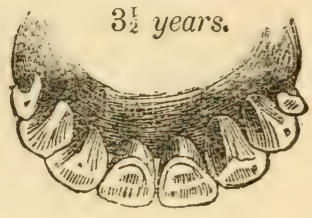

Fig. 35.

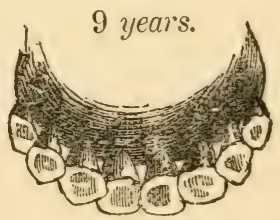

Fig. 37. 


\section{AGE OF THE DOG.}

At birth, the pup has generally all its incisives teeth. At that time his eyes are closed and remain so until the twelfth to fifteenth day. At two months begins the appearance of the permanent teeth. At five months all the incisives and tusks are replaced by adult teeth; at eight months their growth is complete.

Large dogs make teeth sooner than little ones.

At one year, their teeth are fresh and without wear (Fig. 38).

At two years (Fig. 39), wearing of the lower nippers and disappearance of the trifolium shape. 
32

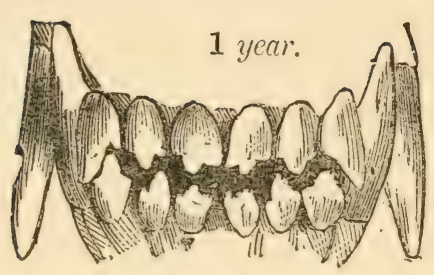

Fig. 38.

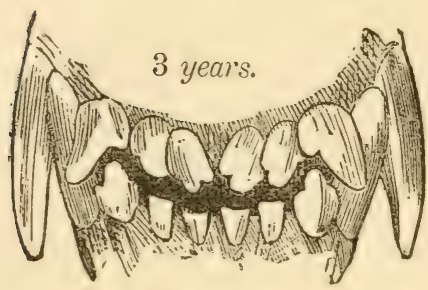

Fig. 10.

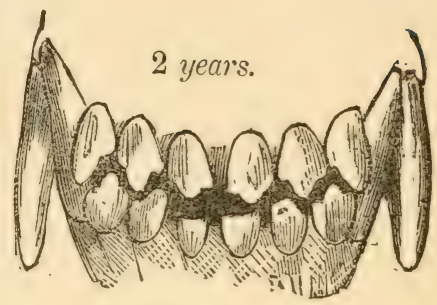

Fig. 39.

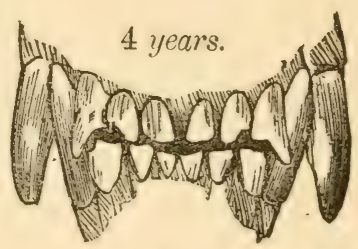

Fig. 41.

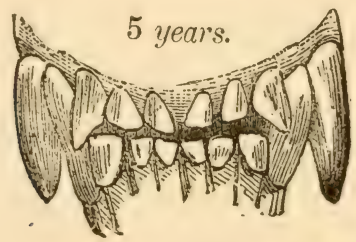

Fig. 42.

At three years (Fig. 40) loss of the trifolium shape 


\section{of the Domestic Animals.}

of the inferior middle and beginning of wear on the upper nippers.

At four years (Fig. 41), superior nippers are worn and the teeth are becoming yellow.

At five years (Fig. 42), all the teeth are worn. From that time, it is impossible to tell the animal's age. 



\section{AGE OF THE PIG.}

At birth are found the corners and tusks; and at three or four months the milk incisives are present.

At six months, the lower corners are replaced by the permanent ones, the nippers and middle teeth being somewhat worn.

At eight to eleven months, the caduct tusks are replaced by those of second dentition.

From twenty months to two years, the nippers are replaced by adult ones.

From two and a haif to three year's, the middle teeth undergo the same change. 



\section{William R. Jenkins's \\ Veterinary Books.}

850 SIXTH AVENUE, NEW YORK.

Any of the following books will be sent post paid on receipt of the price; full Catalogue on application.

Animal ('astration. By Dr. A. Liautard. 12mo, illus-

PRICE trated

American Veterinary Review. Edited by Prof. A. Liautard, H.F.R.C.V.S. Issued monthly. Subseription, \$4 per year; single copy...........................

Armatage. "Every Man His Own Horse Doctor." ' In which is embodied Blaine's "Veterinary Art," with 330 original illustrations, colored plates, anatomical drawings, ete. $8 \mathrm{vo}$, half leather.................. 750

Armatage's Veterinarian's Pocket Remembrancer. By George Armatage, M.R.C.V.S., with concise directions and memoranda for the treatment in urgent or rare

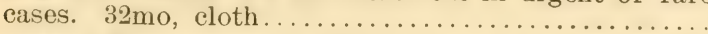

Armatage. Horse owners' and Stable-men's Guide. Crown

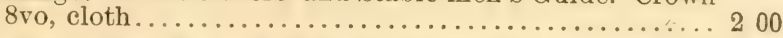

Baucher. New Method of Horsemanship. Including the Breaking and Training of Horses. 12mo, cloth, illustrated

Chaurean. The Comparative Anatomy of the Domesticated Animals. By A. Chauveau, Professor at Lyons Veterinary School, France. New edition, translated, enlarged, and revised. By George Fleming, F.R.C.V.S. $8 \mathrm{vo}$, cloth, with 450 illustrations . . 
Clok. "The Diseases of Sheep." With proper Remedies PRICE to Prevent and Cure the same. By Henry Clok, V.S. $12 \mathrm{mo}$, cloth...............................\$1

Clarke. Horse's Teeth. A Treatise on their Mode of Development, Physiological Relations, Anatomy, Pathology, Dentistry, etc. By W. H. Clarke. Revised, enlarged, and illustrated edition. 12mo, eloth..........

Clater's "Every Man His Own Cattle Doctor." By Francis Clater. New edition, entirely rewritten by George Armatage, with numerous plain and colored plates. 8 vo, half leather..................... 750

Cobbold. "The Internal Parasites of our Domesticated Animals." A manual of the entozoa of the ox, sheep, dog, horse, pig, and eat. By T. Spencer Cobbold, MI.D., F.R.S. 12mo, eloth, illustrated...............2 200

Dalziel. "British Dogs." Their Varieties, History, Charaeteristies, Breeding, Manarement, and Exhibition. Illustrated with full page portraits. $12 \mathrm{mo}$, cloth...... 400

Dalziel. Diseases of Dogs. 12mo, eloth............ 100

Dana. "Tables in Comparative Physiology." Giving Comparative Weight, Temperature, Circulation of the Blood, Respiration, Digestion, Nervous Force and Action between Man and the Lower Animals and Birds. By Prof. C. L. Dana, II.D. Chart on paper...

Day. The Race Horse in Trainiug. With some hints on Racing and Racing Reform. By Wm. Day. Demy 8 vo

DuII. Veterinary Medicines. Their Actions and Uses. By Finlay Dun, V.S. New American edition from the latest English one: 8vo, cloth................. 350 New Revised English editinn, 8vo, cloth.......... 500

Fearnley. Lessons in Horse Judging, and on the Summering of Hunters. 12mo, cloth, illustrated...... . I 60

Fearnley. Lecture on the Examination of Horses as to Soundness, Sale, and Warranty. By W. Fearnley, M.R.C.V.S. $12 \mathrm{mo}$, eloth.................... 300

Fitzwygram. Horses and Stables. By Col. F. Fitzwygram of the 15th Hussars. New edition. With 24 illustra. tions. Cloth ............................. 400

Fleming. "Human and Animal Variolæ." A study in Comparativ́e Pathology. Paper...................

Fleming. "The Contagious Diseases of Animals." Their Influence on the Wealth and Health of Nations. 12mo,

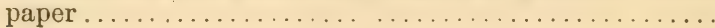


Fleming. "Actinomykosis." A New Infectious Disease of Man and Animals. By George Fleming, F.R.C.V.S. Paper. (Just published.).................... \$0 25

Fleming. On Horseshoeing. By Geo. Fleming. Cloth... 75

Fleming. Operative Veterinary Surgery. By George Fleming. (In Preparation.) Part 1 now ready.

Fleming. Propagation of Tuberculosis. By George Fleming. Cloth

Fleming. Manual of Veterinary Science and Sanitary Police. Embracing the Nature, Causes, Symptoms, etc., and the Prevention, Suppression, Therapeutic Treatment, and the Relation to the Public Health of the Epizootic and Contagious Diseases of the Domesticated Animals; with a scheme for Veterinary and Sanitary Organization; Observations on the Duties of Veterinary Inspector's. Legislative Measures, Inspection of Meat and Milk, Slaughter Houses, ete. Ky George Fleming, F.R.G.S. 2 vols., 8vo, cloth, illustrated..... 900

Fleming. "Animal Plagues." Their History, Nature, and Prevention. By George Fleming, F.R.C.V.S., etc. Being a Chronologieal History from the earliest times to 1844. First Series, comprising a History of Animal Plagues from B.C. 1490 to A.D. 1800 . 8vo, cloth.....6 600 Second Series, containing the History from A. D. 1800 to 1844 . 8vo, eloth, (recently published) $\cdots \ldots \ldots \ldots 480$

Fleming. Veterinary Obstetrics. Including the Accidents and Diseases incident to Pregnancy, Parturition, and the Early Age in Domesticated Animals. By Geo. Fleming, F.R.C.V.S. With 212 illustrations. 8vo, cl. 600

Fleming's Rabies and Hydrophobia. History, Natural Causes, Symptoms, and Prevention. By George Fleming, M.R.C.V.S. 8 vo, eloth..............60 60

Going. Veterinary Dictionary. Compiled by Prof. J.A.Going. 200 Hayes. Veterinary Notes for Horse Owners. An Everyday Horse Book. Revised edition, illustrated, By M. H. Hayes. $12 \mathrm{mo}$, cloth.

Heatley. The Horse-owners' Safeguard. A handy Medical Guide for every Horse-owner. By George S. Heatley,

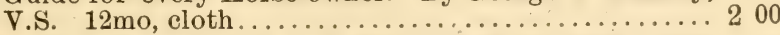

Hill. The Management and Diseases of the Dog. Containing full instrurtions for Breeding, Rearing, and Kennelling Dogs. Their different Diseases, embracing Distemper, Mouth, Teeth, Tongue, Gullet, Respiratory Organs, Hepatitis, Indigestions, Gastritis, St. Vitus' Dance, Bowel Diseases, Paralysis, Rheumatism, Fits, 
Rabies, Skin Diseases, Canker, Diseases of the Limbs, Fractures, Operations, ete. How to letect and how to cure them. Their Medicines, and the Doses in which they can be safely administered. By J. Woodroffe Hill, F.R.C.V.S. $12 \mathrm{mo}$, eloth extra, fully illustrated. .\$2 00

Hill. "The Principles and Practice of Bovine Medicine and Surgery." By J. Woodroffe Hill, F.R.C.V.S. Octavo, 664 pages, with 153 illustrations on wood and 19 full page colored plates. Cloth............... 1000

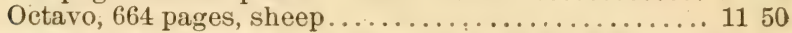

Holcombe. "Laminitis." A Contribution to Veterinary Pathology. By A. A. Holcombe, V.S. Pamphlet.....

Horses and Roads ; or, How to Keep a Horse Sound on his Legs. By" Free Lance"..................... 250

Howden. "How to Buy and Sell the Horse." The object of this book is to explair in the simplest manner what constitutes a sound horse from an unsound one. $12 \mathrm{mo}$, eloth.

Jennings. Horse Training Made Easy. A Practical System of Educating the Horse. By Robert Jennings, V.S. $12 \mathrm{mo}$, eloth.

Jennings. Swine, Sheep, and Poultry. Embracing the History and Varieties of each; Breeding, Management, Disease, ete. By Robert Jennings, V.S. 12mo, cloth. 125

Jennings. Cattle and their Diseases; with the best Remedies adapted to their Cure. By Robert Jennings, V.S. $12 \mathrm{mo}$, cloth.

Jennings. "The Horse and his Diseases." By Robert Jennings, V.S. 12mo, cloth.

Journal of Comparative Medicine and Surgery. A Quarterly Journal devoted to the Diseases of Animals, particularly of the Horse. Published in January, April, July, and Octuber. Subscriptions, \$2 per annum. Single copies, postpaid.

Laverack. The Setter. By E. Laverack. With instructions how to Breed, Rear, Break, ete. Colored illustrations.

Liautard. Vade Mecum of Equine Anatomy. By A. Liautard, M.D., V.S. $12 \mathrm{mo}$, cloth.................. 175

Liautard. "Animal Castration." By Dr. A. Liautard, D.V.S. $12 \mathrm{mo}$, illus:

Liaitard. Translation of Zundelion the Horse's Foot. By Dr. A. Liautard, D.V.S. 8vo, cloth. 
monia. Illustrated. By James Law, Professor of Teter-

inary Medicine in Cornell University. Paper, 100 pp .\$0 30

Law. Farmers' Veterinary Adviser. A Guide to the Prevention and Treatment of Disease in Domestic Animals. By James Law, Professor of Veterinary Medicine in Cornell University. Illustrater. 8vo, cloth.

Lehndorff. Horsebreeding Recollections. By G. Lehndorff. 8 vo, eloth......................... 420

Martiu. Cattle. Their Various Breeds, Management, and Diseases. By W. C. L. Martin. Revised by W. Rayn.

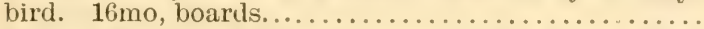

MeAlpine. Biological Atlas. Containing 24 plates of 423 colored illustrations. Oblong quarto cloth. By D. MeAlpine, F.C.S

McBride. Anatomical Outlines of the Horse. Revised and Enlarged by T. M. Mayer, M.R.C.V.S. With colored

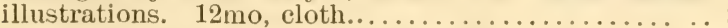

McClure. Diseases of American Horses, Cattle, and Sheep. Their Treatment; with full description of the Medicines employed. By R. MøClure, M.D., V.S. 12mo, cl., illus. 200

McClure. American Gentlemen's Stable Guide; with the most Approved Methods of Feeding, Grooming, and Managing the Horse. By Robert MeClure, M.D., V.S.

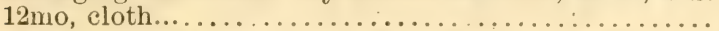

Meyrick. Stable Management and the Prevention of Diseases among Horses in India. By J. J. Meyrick, F.R.C.V.S.

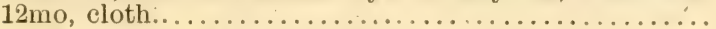

Miles. Remarks on Horses' Teeth. Addressed to Purchas-

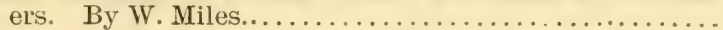

Moreton. "On Horsebreaking." By Robert Moreton. $12 \mathrm{mo}$, cloth..

Moreton's Manual of Pharmacy for the Veterinary Student. By J. W. Morton. 12mo, eloth.............. 400

Navin. "The Explanatory Stock Doctor," for the use of the Farmer, Breeder, and Owner of the Horse. With numerous illustrations. By John Nicholson Navin, V.S. 8vo, sheep.

Percival. Hyppo-pathology. A Systematic Treatise on the Disorder's and Lameness of the Horse. By IV. Per cival. With many illustrations. 6 vols., boards.....34 20

Percival. Lectures on Horses; Their Form and Action. By W. Pereival. With eight outline plates. 8vo, ćloth. 400 Percival's Anatomy of the Horse. By W. Percival. 8vo, cloth................................ 800 
Peck. "Classifications of the Muscles of the Horse." This is a large chart, printed on heavy paper, $24 x 38$ inches, showing at a glance the Classifications of the Muscles of the Horse, with Origin, Insertion, Nervous Supply, and the Function of each..................... \$0 50

Reynolds. "Breeding and Management of Draught Horses.'

By Richard S. Reynolds, M.R.C.V.S. Crown 8vo, cl.... 140

Riley. The Mule. A Treatise on the Breeding, Training, and Uses to which he may be put. 12mo, cloth, illus.. 150

Robertson. The Practice of Equine Medicine. By W. Robertson...........................6 600

Steel. A Treatise on the Diseases of the Ox. Being a Manual of Bovine Pathology, especially adapted to Veterinary Practitioners and Students. By John Henry Steel, M.R.C.V.S., F.Z.S. 8vo, with 118 illus., cl.....6 600

Steel. "Outlines of Equine Anatomy." A Manual for the use of Veterinary Students in the Dissecting Room. By John H. Steel, M.R.C.V.S. 12mo, cloth.

Strangeway. "Veterinary Aratomy." New edition, revised and edited by I. Vaughn, F.L.S., M.R.C.V.S., with several hundred illustrations. 8vo, eloth........8 800

Stormonth's Manual of Scientific Terms. Especiaily referring to those in Botany, Natural History, Medical and Veterinary Science. By Rev. Jas. Stormonth .....

Tellor. "Diseases of Live Stock," and their most Efficient Remedies. By Lloyd V. Tellor. 8vo, cloth, illustrated, \$2.50; sheep. .

Tuson. Pharmacopœia, including Outlines of Materia Medica and Therapeutics in Veterinary Medicine. By R. V. Tuson. 12mo, eloth . . .

Veterinary Diagrams. Five Charts, each $22 \times 28$ inches in size, on stout paper, as follows, sold separately :

No. 1, with eight colored illustrations. Lxternal Form and Elementary Anatomy of the Horse.............

No. 2. Unsoundness and Defects of the Horse, with

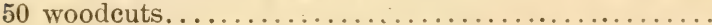

No. 3. The Age of the Domestic Animals, with 42 woodcuts.

No. 4. The Shoeing of the Horse, Mule, and Ox, with 59 woodcuts.

No. 5. The' Elementary Anatomy, Points, and Butcher's Joints of the Ox, with 17 colored illustrations. With

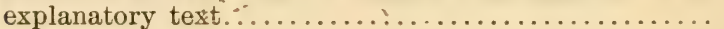
Price per set of five. 
Walley. "Four Bovine Scourges." (Pleuro-Pneumonia, Foot and Mouth Disease, Cattle Plague, and Tubercle., With an Appendix on the Inspection of Live Animals and Meat. By Thos. Walley, M.R.C.V.S. With 49 colored illus. and numerous woodeuts. 4to, cl.......\$6 40

Webb. "On the Dog." Its Points, Peculiarities, Instsinct, and Whims. Illustrated with photographs........ 300

Williams. Principles and Practice of Veterinary Medicine. New edition, entirely revised. and illustrated with numerous plain and colored plates. By W. Williams, M.R.C.V.S. 8vo, eloth.................... 500

Williams. Principles and Practice of Veterinary Surgery. New edition, entirely revised, and illustrater with numerous plain and colored plates. By W. Williams, M.R.C.V.S. 8vo, eloth....................... 750

Williams. Chart of the Contagious, Infectious, and Specific Fevers of the Domesticated Animals............. 100

Zundel. "On the Horse's Foot." Translated by A. Liautard, M.D., D.V.S...................... 150

\section{VETERINARY BOOKS IN FRENCH.}

Benion. Traité de l'Êlevage et des Maladies des Animaux et des Oiseaux de Basse-Cour..................\$2 80

Benion. Traité de l'Élevage et des Maladies du Mouton. . 360 Benion. Traité de l'Elevage et des Maladies du Pore. . . . 260

Beugnot. Dictionnaire usuel de Chirurgie et de Médecine Vétérinaire. 2 forts volumes in-8, avec planches..... 720

Bouley. La Rage, moyen d'en éviter les Dangers et de

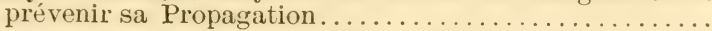

Bouley-Reynal. Nouveau Dictionnaire Pratique de Médecine, de Chirurgie et Hygiène Vétérinaire (to be completed in 18 volumes), chaque volume..............

Colin. Traité de Physiologie Comparée des Animaux; Par G. Colin, Professeur à l'école Vétérinaire d'Aliort; avec Figures intercalées dans le texte. 2 vols. in-8. . 1040

Cruzel. Des Maladies de l'Espèce Bovine. Par J. Cruzel. 560 Dictionnaire. Lexiengraphique et Descriptif des Sciences Médicales et Vétérinaires. Un très-fort vol. de plus de 1500 pages............................... 800

Gourdon. Traité de la Castration des Animaux Domestiques 360 
Hertwig. Les Maladies des Chiens et leur Traitement. . \$1 40

Lecocq. Traité de l'Extérieur du Cheval et des Princip aux Animaux Domestiques........................3 60

Leyh. Anatomie des Animaux Domestiques.......... 360

Magne. Races Chevalines et leur Amélioration, Entretien, Multiplication, Elevage et Éducation du Cheval, de l'Ane et du Mulet. Par J. H. Magne.............. 320

Magne. Races Bovines et leur Amélioration, Entretien, Multiplication, Elevage et Engraissement du Bœuf. Par J. A. Magne .............................. 200

Magne. Races Porcines et leur Amélioration, Entretien, Multiplieation, Élevage et Engraissement du Porc. Par J. H. Magne... ....................... . 80

Magne. Nourriture des Chevaux de Travail-brochure.. .. 40

Magne. Choix $d u$ Cheval ..................... 80

Magne. Choix et Nourriture du Cheral. Par J. H. Magne.

Avec Vignettes. .............................. 140

Mourod. Matiere Médicale; ou la Pharmacologie Vétérinarie.2 40

Saint-Cyr. Traité d' Obstétrique Vétérinaire. Avec cent vignettes .................................. 560

Signol. Aide Mémoire du Vétérinaire, Médecine, Cuirurgie et Obstétrique; Par Jules Signol; avec 395 Figures... 240

Tabourin. Nouveau Traité de Matière Médicale Thérapeutique et de Pharmacie Vétérinaires, 2 fort volumes, in- 8 , avec plus de 100 figures. . . . . . . . . . . . . . . 800 





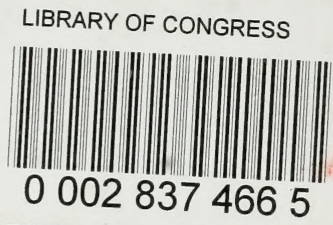

